\title{
Favourable uranium-phosphate exploration trends guided by the application of statistical factor analysis technique on the aerial gamma spectrometric data in Syrian desert (Area-1), Syria
}

\author{
J Asfahani*, R Al-Hent and M Aissa \\ Atomic Energy Commission, P.O. Box 6091, Damascus, Syria. \\ ${ }^{*}$ Corresponding author.e-mail: cscientific@aec.org.sy
}

A scored lithological map including 10 radiometric units is established through applying factor analysis approach to aerial spectrometric data of Area-1, Syrian desert, which includes Ur, eU, eTh, K\%, eU/eTh, $\mathrm{eU} / \mathrm{K} \%$, and $\mathrm{eTh} / \mathrm{K} \%$. A model of four rotated factors F1, F2, F3, and F4 is adapted for representing 234,829 data measured points in Area-1, where $86 \%$ of total data variance is interpreted. A geological scored pseudo-section derived from the lithological scored map is established and analyzed in order to show the possible stratigraphic and structural traps for uranium occurrences associated with phosphate deposits in the studied Area-1. These identified traps presented in this paper need detailed investigation and must be necessarily followed and checked by ground validations and subsurface well logging, in order to locate the anomalous uranium occurrences and explore with more confidence and certitude their characteristics as a function of depth.

\section{Introduction}

An airborne gamma-ray spectrometric survey was undertaken in Syria during a project conducted in 1987 in cooperation with the International Atomic Energy Agency and Riso National Laboratory SYR/86/005 (Riso 1987; Jubeli 1990). The airborne radiometric survey was carried out at a nominal survey height of $30 \mathrm{~m}$, at an average speed of $120 \mathrm{~km} / \mathrm{hr}$ along parallel lines with a spacing of $3-4 \mathrm{~km}$ to cover most of the interested areas in Syrian territory, using a compact lightweight, four window gamma-ray spectrometer (Scintrex, GAD-6, Canada) with a detector of $12.5 \mathrm{~L}(\mathrm{NaI})$ volume. The detector was maintained at a constant temperature and the gain was stabilized before recording each mission. The system calibration took place at the calibration pads of the Dafa airport in Sweden (Riso 1987). An IGI Loran-C navigation system was used to provide efficient flight path control. It defines and records automatically all waypoints and fiducials of flight tracks along the flight lines. Raw data were recorded with $1 \mathrm{~s}$ intervals, corrected for background effects, and the applicable interchannel Compton corrections, the exponential factors for height corrections were established.

This airborne survey was carried out in the following areas (figure 1a):

1. The Syrian desert (Area-1) (7189 line $\mathrm{km}$ at 4 $\mathrm{km}$ line spacing)

2. Ar-Rassafeh Badyieh (Area-2) (2240 line km at $4 \mathrm{~km}$ line spacing)

3. The Northern Palmyrides (Area-3) (1600 line km at $3 \mathrm{~km}$ line spacing)

Keywords. Phosphate and uranium prospecting; aerial spectrometry survey; stratigraphic-structural traps; Syrian desert; Syria. 


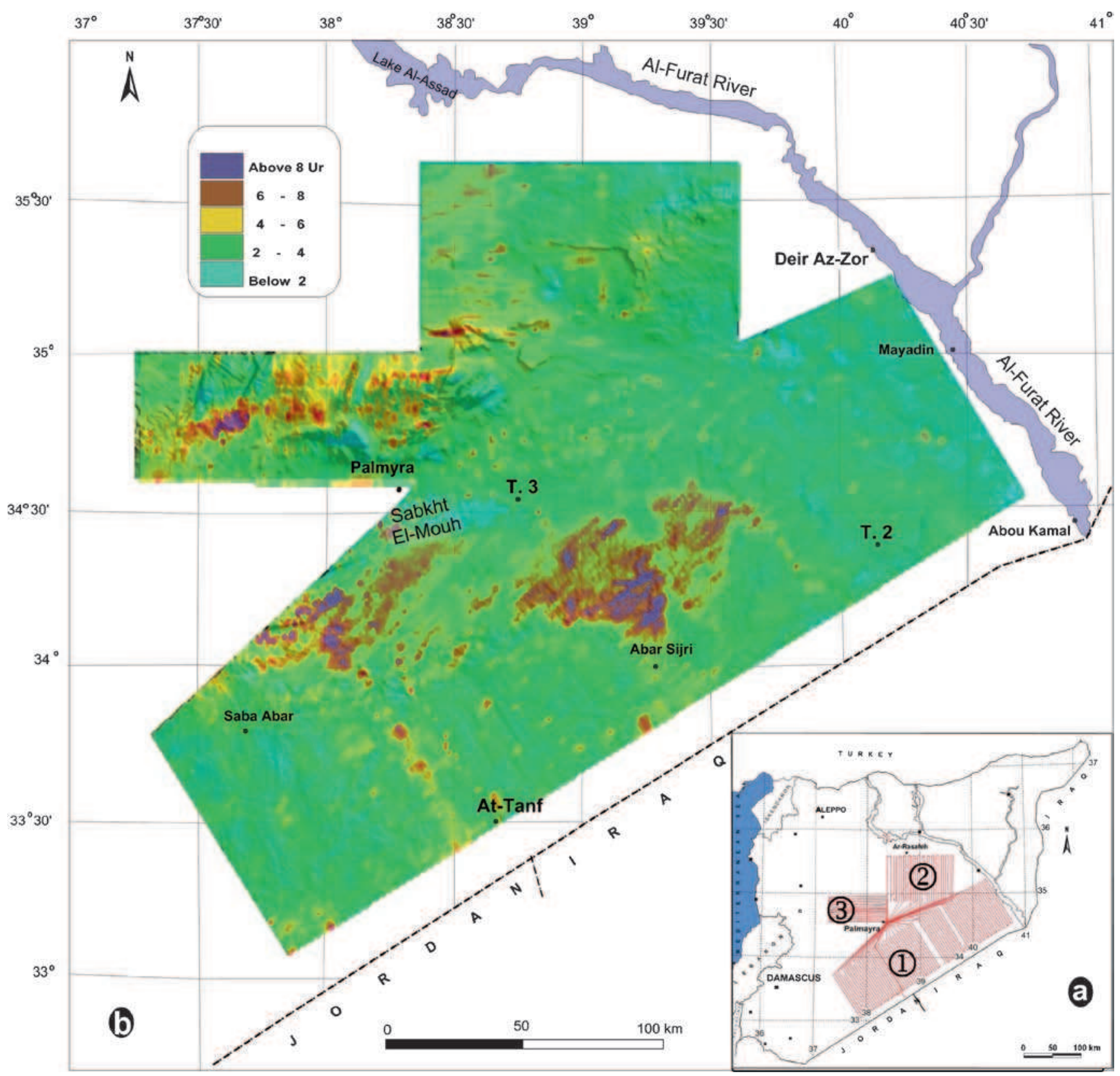

Figure 1. (a) Total areas covered by airborne gamma-ray spectrometry in Syria. (b) Radiometric map resulting from spectrometric survey.

Figure 1(b) shows the Syrian areas surveyed by airborne gamma-ray spectrometry and the total radiometric map (Ur).

It was found that gamma-ray anomalies are mainly associated with phosphate deposits encountered in Syrian desert and other parts in Syria. Hunting Geology and Geophysics (1975) found an indirect and non-linear relationship between radioactivity and $\mathrm{P}_{2} \mathrm{O}_{5}$. Jubeli (1997) found a linear relationship between the values of $\mathrm{P}_{2} \mathrm{O}_{5}$ and total radioactivity, as well as eU determined by gammaray spectrometry. This relationship is valuable only for $\mathrm{P}_{2} \mathrm{O}_{5}$ up to and not exceeding $20 \%$ and above this level, this linearity was not as good (Jubeli 1997).
The present paper concentrates on the application of advanced statistical factor analysis technique on the aerial gamma spectrometric data of Area-1 for lithological discrimination, identification of radioactivity anomalies and potential horizons for prospecting as previously done for Area-3 (Asfahani et al. 2005).

The importance of the study area is related to two essential points:

1. Significant phosphate deposits (Khneifis and AlSharquieh mines) are located $65 \mathrm{~km}$ and $45 \mathrm{~km}$ southwest of Palmyra, respectively (figure 2).

2 . The study area is characterized by favourable geological, tectono-structural and geochemical 


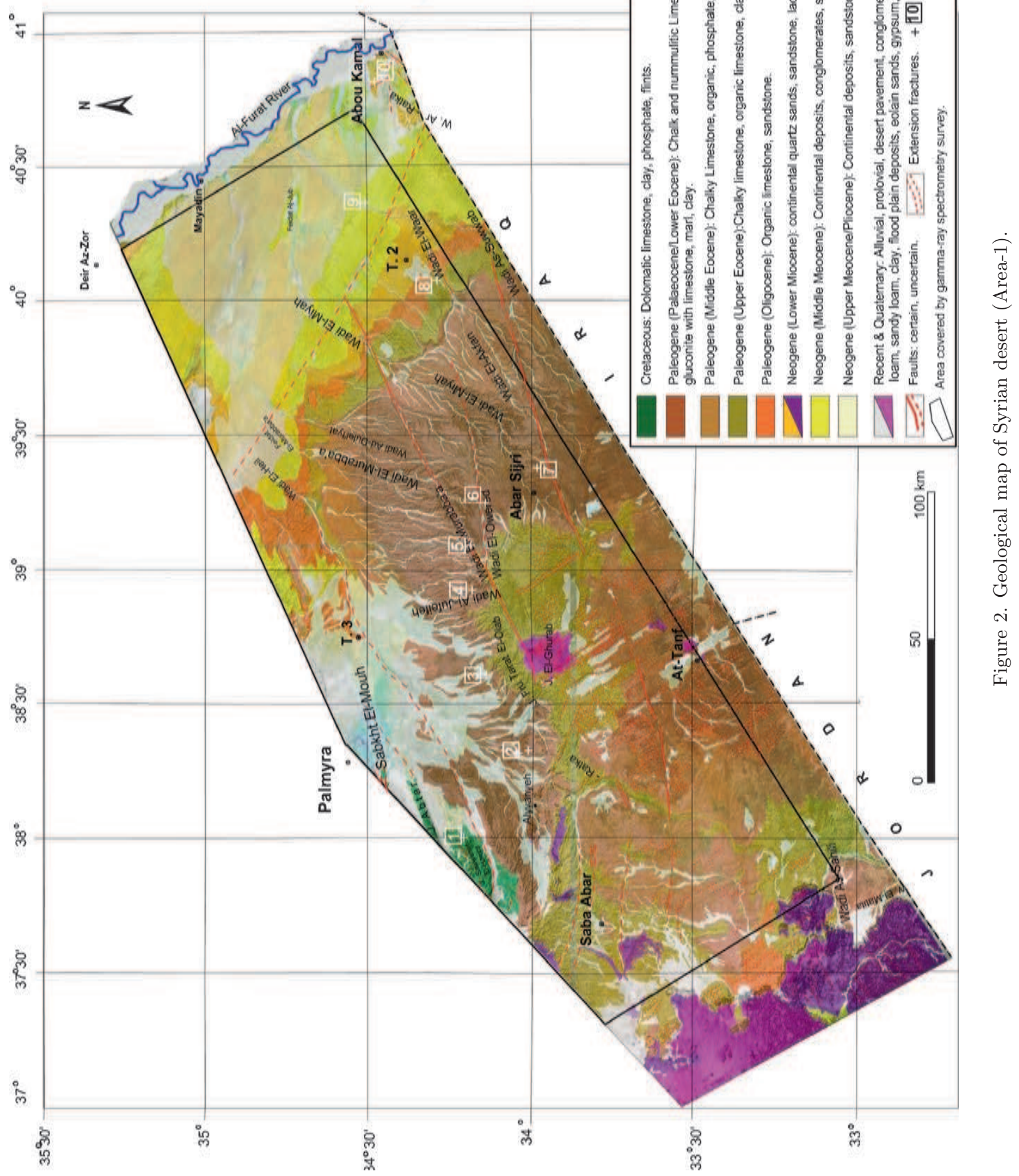


conditions for uranium prospecting suitable for uranium fixation in phosphate rocks (Jubeli 1997). Most of the secondary uranium mineralization is found as blooms, stains or hatches of greenish yellow colours along the cleavage cracks, joints and pores of marly limestone and sandstone of Paleogene age, with the assumption that phosphate is the most significant source for uranium in the studied desert region (Technoexport 1966).

Uranium occurrences in the study area are scattered and deposited along the flanks of the wadis, and the secondary uranium mineralization is classified (International Atomic Energy Agency 1988; Jubeli 1990) as surfacial minerals (Dahlkamp 2009; International Atomic Energy Agency 2014).

A scored lithological map including 10 different identified geological units is established through interpreting the airborne gamma-ray spectrometric data of Syrian desert (Area-1) by the factor analysis technique. A model of four factors (F1, F2, F3 and F4) is sufficient for representing the acquired data, where $86 \%$ of the total data variance is explained.

\section{Factor analysis procedure}

The aerial spectrometric data of the Syrian desert (Area-1) are subjected to a quantitative factor analysis technique in order to differentiate various geological units, based on the established lithological scored map for the study area.

Using factor analysis technique, a system of new factors is obtained through the transformation of the seven radiometric variables (Ur, eU, eTh, K\%, $\mathrm{eU} / \mathrm{eTh}, \mathrm{eU} / \mathrm{K} \%$, and $\mathrm{eTh} / \mathrm{K} \%$ ) of the study area. Those new factors are constrained to reproduce as much as possible the total variance of the original data. Each original data point gains factor score, representing the affiliation of the samples to the newly defined factors. The plotting of these new factor produces a set of new maps. The new maps are qualitatively compared with the available geological map in order to extract the geological characteristics. This step serves as a tool in reinterpreting the data to provide direct differentiation of all the geological units depending on the established lithological scored map.

\section{General setting}

\subsection{Topography}

Area-1 is topographically divided into two parts:

1. The mountainous part of small area, occupying the northwestern tract. It is represented by a number of short ridges of the northeastern trend, belonging to the Palmyrian ridge system.

2. Typical stony desert part covering the south and southeastern parts of the tract of slightly undulating flat surface, with some rises to the middle (Jabal Fru Tarat El-Olab, Jabal ElGhurab). The southwestern tract is widely covered by the effusive rocks, where numerous volcanic cones exist and are grouped into chains of northwestern trend.

The remaining part of Area-1 is slopping south and southeastward, where the Al-Furat river valley almost extends in the merdional direction. The drainage network is poorly developed, where the wadis are comprising dry water courses. Those wadis are usually filled with the water only during the rainy seasons, where the surface water flow is very rapid and enough to carry the clastic sediments into the depressions in which many wadis are terminated to the temporary lakes (Feidat, takyrs) after heavy rains (Technoexport 1966).

\subsection{Geology}

Cretaceous to Recent are mostly exposed in the study area (figure 2), with several regional and local unconformities (Technoexport 1966; Bender 1974).

Cretaceous system is exposed in the mountain parts of southern Palmyride ridge (J. Abtar, J. Sawwanet El-Hamra), and consists of organic limestones, dolomatic limestones, marl-clayey limestone with nodular-granular phosphates and flint intercalations. Cretaceous rocks partially or wholly disappear towards southeast, with long depositional hiatus (Technoexport 1966; Al-Bassam et al. 2006; Caron and Mouty 2007).

Paleogene system is exposed in the northwestern part of the study area. The Paleogene sequences are represented as marine, shallow marine and pass into continental lithofacies towards northeast and east. There are variety of rocks composing the Paleogene deposits such as fine-grained limestone, organic limestone, sandy limestone, chalk-like marly limestone, massive marl containing remnants of fish and organic phosphotized fragments, phosphate beds, and granular-glauconitic sandstone with abundant flint lenses (Technoexport 1966; Bender 1974). The jointed and porous limestone of lower/middle Eocene usually contains yellow coloured calcium carnotite (Alyyanyeh, At-Tanf).

Neogene system usually covers vast area and sometimes overlies the Paleogene rocks with unconformity. The Neogene is composed of variable 
complexes of deposits. They are started when coastallagoonal facies pass through lacustrine-continental of Pliocene strata. The upper beds of Neogene sequence show transition from lagoonal-marine to deltaic and continental facies.

Quaternary and recent system is composed of prollovial, alluvial, lacustrine, sometimes conglomerate rocks covered by carbonate chemogenic crusts and immature surface soils. These deposits occupy in general both the wadis (Al-Furat) river valley and its tributaries (wadi El-Miyah, w. AsSuwwab, w. El-Waar and w. Ar-Ratka), stony plain faidat, playa-lakes (Sabkhet El-Mouh, feidat elEl-Murabba'a, feidat Aj-Jub), and the developed series of evaporative pans (takyrs).

Basalt: Various lava flows are effused from southern Syria (J. Al-Arab) and cover many districts of the southwest part of the study area. The basalt plates grade towards south and unconformably cover the older rocks. Majority of the basalts were erupted from the volcanic chains and latitudinal extension fissures. The age of the basalt in the study area from the upper Neogene (Pliocene) to late Pliestocene. The basalt also exists in the middle, south and southwest of the study area (J. El-Ghurab, At-Tanf, Saba Abar and Khabret As-Sawwaneh (As-Sahili) respectively).

The subsurface of intrusive lava bodies formed a pyroclastic accumulation with flint and limetone fragments known as desert pavement (Khabret AsSawwaneh (As-Sahili), At-Tanf).

\subsection{Tectonic}

Syrian desert falls in the stable part of the Arabian desert (Technoexport 1966; Bender 1974). The Palmyrian fault-zone forms the northern limit of the stable part. No clear vertical structural relieves appear on the surface, while the subsurface structures are detected by geophysical methods and data logs.

The tectonic activity took place on the platform causing structural and lithofacial changes, where Mesozoic and Cenozoic rock units are exposed, gently slopped towards northeast.

Important structural features that delineated the study area are as follows:

Rutbah-Hamad uplift: A broad anticline with core is located at the western Iraq desert and extends towards north Jordan and southern Syria. The northern slope of this broad uplift is bounded by dome-like anticlines, which is separated from each other by many small synclines and truncated by many faults of northeast, southwest trending (w. El-Murabba'a, w. As-Suwwab, At-Tanf, and w. Akfan).

Palmyride ridge: Linear asymmetric anticlines, with steeper and trusted southeast side. The anticlines are separated by synclines and trend towards northeast (J. Abtar, J. Sawwanet El-Hamra).

Fault systems: Two main lineaments NW-SE and NE-SW are deduced from landsat images (Technoexport 1966; Sissakian 2007; Rukieh et al. 2005).

1. Northeast-southwest trending: Most of the temporal drainage network are governed by these fault systems. Faults and ruptures cut all the northern slope of Rutbah-hamad uplift and Palmyride ridge (w. As-Suwwab, w. El-Waar, w. El-Akfan and w. El-Heil).

2. Northwest-southeast trending: The main fault systems are formed by horsts and grabens, and sometimes with strike-slip movement (Al-Furat, Al-Feidat fault system).

3. Extension fissure swarms: These fissure swarms exhibit almost meridional (E-W) trend, and are usually accompanied with perpendicular ruptures. Basaltic lava are effused through such fissures and form basalt cover sheets (figure 2).

\section{Results and discussion}

The aerial gamma-ray spectrometric data related to Area-1 were subjected to single and bivariate statistical analysis technique to characterize the seven aerial radiometric variables as shown in table 1. The maximum eU in Area- 1 is $32.74 \mathrm{ppm}$, with an average of $1.90 \mathrm{ppm}$ and a standard deviation $\sigma$ of $1.39 \mathrm{ppm}$. Higher values of uranium, more than $4.67 \mathrm{ppm}$ are considered as anomalous eU values (Gavshin et al. 1974; Asfahani et al. 2009). Uranium also exhibits a relatively high value of coefficient of variability CV\% (73\%), in comparison with those of eTh (32\%) and K\% (37\%). The high CV\% value for uranium is due to the higher mobility of the uranium as compared to eTh and $\mathrm{K} \%$, which are characterized by higher stability under the same conditions (Asfahani 2002; Asfahani et al. 2005, 2007, 2010a).

Table 2 shows the correlation analysis results and the coefficients between the seven radiometric variables obtained while interpreting the data of Area-1.

This correlation matrix shows a cluster of positive correlation between three variables (Ur, eU, and $\mathrm{eU} / \mathrm{eTh}$ ). Positive correlation has also been found between $\mathrm{K} \%$ and eTh (0.58). 
Table 1. Statistical characteristics of the seven radioactive variables in Syrian desert.

\begin{tabular}{lrrrrrrr}
\hline Variable & \multicolumn{1}{c}{$\mathrm{Ur}$} & $\mathrm{K} \%$ & $\mathrm{eU}(\mathrm{ppm})$ & $\mathrm{eTh}(\mathrm{ppm})$ & $\mathrm{eU} / \mathrm{eTh}$ & $\mathrm{eU} / \mathrm{K} \%$ & $\mathrm{eTh} / \mathrm{K} \%$ \\
\hline Case number & 234829 & 234829 & 234829 & 234829 & 234829 & 234829 & 234829 \\
Min & 0.54 & 0.01 & 0.01 & 0.03 & 0.001 & 0.02 & 0.23 \\
Max & 34.69 & 0.94 & 32.74 & 9.57 & 48.48 & 742.00 & 352.00 \\
$\bar{X}$ & 4.43 & 0.25 & 1.90 & 3.10 & 0.73 & 9.42 & 13.80 \\
$\sigma$ & 1.67 & 0.09 & 1.39 & 0.99 & & & 6.81 \\
$\mathrm{CV}$ & 37.68 & 37.44 & 72.96 & 32.03 & & & 49.36 \\
$\bar{X}+2 \sigma$ & 7.76 & 0.43 & 4.67 & 5.09 & & & 27.42 \\
\hline
\end{tabular}

CV: Coefficient of variability $(=(\sigma / \bar{X}) * 100), \bar{X}$ : Mean, $\sigma$ : Standard deviation.

Table 2. Correlation matrix of seven radiometric variables in Syrian desert.

\begin{tabular}{llrrrrrr}
\hline Variables & $\mathrm{Ur}$ & $\mathrm{K} \%$ & $\mathrm{eU}$ & $\mathrm{eTh}$ & $\mathrm{eU} / \mathrm{eTh}$ & $\mathrm{eU} / \mathrm{K} \%$ & $\mathrm{Th} / \mathrm{K} \%$ \\
\hline $\mathrm{Ur}$ & 1 & & & & & & \\
$\mathrm{~K} \%$ & 0.44 & 1 & & & & & \\
$\mathrm{eU}$ & 0.81 & -0.03 & 1 & & & & \\
$\mathrm{eTh}$ & 0.34 & 0.58 & -0.14 & 1 & & & \\
$\mathrm{eU} / \mathrm{eTh}$ & 0.36 & -0.17 & 0.60 & -0.37 & 1 & & \\
$\mathrm{eU} / \mathrm{K} \%$ & 0.31 & -0.40 & 0.60 & -0.28 & 0.48 & 1 & 1 \\
$\mathrm{eTh} / \mathrm{K} \%$ & -0.11 & -0.46 & -0.03 & 0.20 & -0.10 & 0.50 & 1 \\
\hline
\end{tabular}

Table 3. Eigenvalue of four rotated factors in Syrian desert (Area-1).

\begin{tabular}{llccc}
\hline & $\begin{array}{l}\text { Eigen } \\
\text { value }\end{array}$ & $\begin{array}{c}\text { Total } \\
\text { variance }(\%)\end{array}$ & $\begin{array}{c}\text { Cumulative } \\
\text { eigen value }\end{array}$ & $\begin{array}{c}\text { Cumulative } \\
(\%)\end{array}$ \\
\hline F1 & 2.37 & 33.869 & 2.37 & 33.869 \\
F2 & 2.0122 & 28.745 & 4.3831 & 62.615 \\
F3 & 1.43767 & 20.53814 & 5.8207 & 83.153 \\
F4 & 0.2217 & 3.16754 & 6.0424 & 86.321 \\
\hline
\end{tabular}

The matrix in table 2 is used to obtain seven unrotated loading factors, which are difficult to interpret in geological terms. It is therefore necessary to rotate these seven factors to another form equivalent to the original unrotated matrix. This rotation is achieved by using the Varimax method (Comery 1973), where the system of seven unrotated factors are reduced to only four principal factors F1, F2, F3 and F4 without losing significant information. The results of this rotation are shown in table 3 .

The four rotated factors are quite interpretable and represent $86.3 \%$ of the total system information, which is sufficient to interpret the variable data as shown in table 4.

F1 explains $33.9 \%$ of the total variance, and has high loading values of $0.86,0.97,0.58$, and 0.55 for the variables of total radioactivity $\mathrm{Ur}, \mathrm{eU}, \mathrm{eU} /$ $\mathrm{eTh}$, and $\mathrm{eU} / \mathrm{K} \%$ respectively. This factor, therefore, is composed of these four variables and directly related to the uranium presence in the phosphatic deposits outcropped in Area-1 of Cretaceous and Paleogene ages. According to this F1 factor, four lithofactor A, B, C, and D units have been distinguished.

F2 explains $28.74 \%$ of the variability of geophysical data. It is positively loaded for the $\mathrm{K} \%$ variable (0.51), inversely loaded for the $\mathrm{eU} / \mathrm{K} \%(-0.54)$ and $\mathrm{eTh} / \mathrm{K} \%(-0.97)$. The observed antipathetic relationship of $\mathrm{K}$ with $\mathrm{U}$ and Th suggests that F2 cannot probably be directly used to delineate potential horizons for radio elemental concentration.

This factor is related to the alkalinity, faults, extension fractures, and evaporation under oxidizing arid conditions. It is lithologically connected with marine graded to shallow marine, and shoal deposits of Paleogene age. According to this F2 factor, three lithofactor E, F, and G units have been distinguished in a patchy form and turn into zonal grading-shape towards northeast.

Generally, it is observed that $\mathrm{K}$ and $\mathrm{Na}$ have a sympathetic relationship with radio elements, due to the alkalinity, to the existing limestone with marl clay intercalations and slightly with phosphate beds and silicious concretions. Such assembling litho-facies is due to the prevalence of arid climate 
Table 4. The four rotated factors.

\begin{tabular}{lcccr}
\hline Variables & F1 & F2 & F3 & \multicolumn{1}{c}{ F4 } \\
\hline $\mathrm{Ur}$ & 0.863 & 0.072 & 0.466 & -0.002 \\
$\mathrm{~K} \%$ & 0.041 & 0.511 & $\mathbf{0 . 7 8 3}$ & 0.117 \\
$\mathrm{eU}$ & $\mathbf{0 . 9 7 0}$ & -0.0377 & -0.071 & 0.056 \\
$\mathrm{eTh}$ & -0.0739 & -0.172 & $\mathbf{0 . 8 8 3}$ & -0.199 \\
$\mathrm{eU} / \mathrm{eTh}$ & 0.580 & 0.062 & -0.320 & 0.205 \\
$\mathrm{eU} / \mathrm{K} \%$ & 0.546 & -0.536 & -0.261 & 0.528 \\
$\mathrm{eTh} / \mathrm{K} \%$ & -0.068 & $-\mathbf{0 . 9 6 8}$ & 0.039 & 0.050 \\
\hline
\end{tabular}

Table 5. Factor score coefficients for Syrian desert (Area-1).

\begin{tabular}{lcccc}
\hline Variables & $\mathrm{F} 1$ & $\mathrm{~F} 2$ & $\mathrm{~F} 3$ & $\mathrm{~F} 4$ \\
\hline $\mathrm{Ur}$ & 0.46 & -0.028 & 0.517 & -0.272 \\
$\mathrm{~K} \%$ & -0.132 & 0.204 & $\mathbf{0 . 4 4 5}$ & 0.681 \\
$\mathrm{eU}$ & $\mathbf{0 . 5 7 1}$ & -0.00105 & -0.395 & -0.535 \\
$\mathrm{eTh}$ & -0.0526 & -0.142 & 0.336 & -0.134 \\
$\mathrm{eU} / \mathrm{eTh}$ & 0.0228 & 0.022 & -0.039 & 0.0433 \\
$\mathrm{eU} / \mathrm{K} \%$ & -0.007 & -0.092 & -0.003 & 1.292 \\
$\mathrm{eTh} / \mathrm{K} \%$ & -0.0516 & $\mathbf{- 0 . 8 0 0}$ & 0.221 & -0.295 \\
\hline
\end{tabular}

and poor drainage network with gentle topography (Erd'ly and Galfi 1986). The capillarity action in such arid conditions plays a role for percolation solutions upward, where their salts precipitate in the topsoils as it appears in G and E lithofactor units. Also, most of the $\mathrm{K}$ halos appear mainly along the faults and fractured zones as seen in the $\mathrm{F}$ lithofactor unit. $\mathrm{K}$ and Th concentrate colloidally in mud-fillings along such faulted zones. The mutual relationships between the different distinguished units of F2 could be used indirectly for detecting radioactive anomalous occurrences.

F3 explains $20.54 \%$ of the data variability, and is highly loaded with $\mathrm{K} \%$ (0.78) and eTh (0.88). This factor is related to the closed basins and evaporative pans, and steeply accompanied with continental lithofacies of Neogene age. According to F3 factor, three lithofactor $\mathrm{H}$, I, and J units have been distinguished.

F4 explains only $3.2 \%$ of the data variability, and is loaded with eU/K\% (0.53). It is difficult at this stage for F4 to be geologically interpreted.

The factor score coefficients shown in table 5 are used to construct the three standard factor scored maps for F1, F2 and F3, for Area-1 as shown in figures 3,4 and 5 .

The comparison between the established scored map and the geological map of the study area allows to characterize the 10 differentiated lithofactor units according to F1, F2, and F3.

Four lithofactor phosphatic units of Cretaceous and Paleogene ages have been distinguished according to the F1 scored map (figure 3). Those units are classified from the top to downwards as follows:

A: comprises various phosphate beds, highly weathered and leached, which release significant amounts of secondary uranium minerals, that flow through the rock spacing and conduits, and are mostly concentrated at adjoining tracts, or along the faulted and fractured zones, due to deep-seated ascending solutions movement. The range of this unit exceeds 300 on the F1 scored map.

B: comprises silicified and calcified phosphate rocks, preferentially affected by weathering and leaching processes, that yield to liberate limited amounts of secondary uranium minerals. The range of this unit varies between 200 and 300 on the F1 scored map.

$\mathrm{C}$ : comprises aggregate of silicified, phosphotized and carbonate lithofacies, accompanied with weathering products from the adjacent rocks. Moreover, these facies may be saturated with the ascending fluid solutions that flow through the faulted and fractured zones and through the rock spacing and conduits. Such lithofacies are capable of forming potential traps for secondary uranium mineralization (Dickson and Wheller 1992). The range of this unit varies between 100 and 200 on the F1 scored map (Asfahani et al. 2010b).

D: comprises crescent-shaped zone (figure 3) of lithofacies of low radioactivity, reflecting the elongation and trends of detritus, alluviums in temporal wadis. It can be termed as the channel 


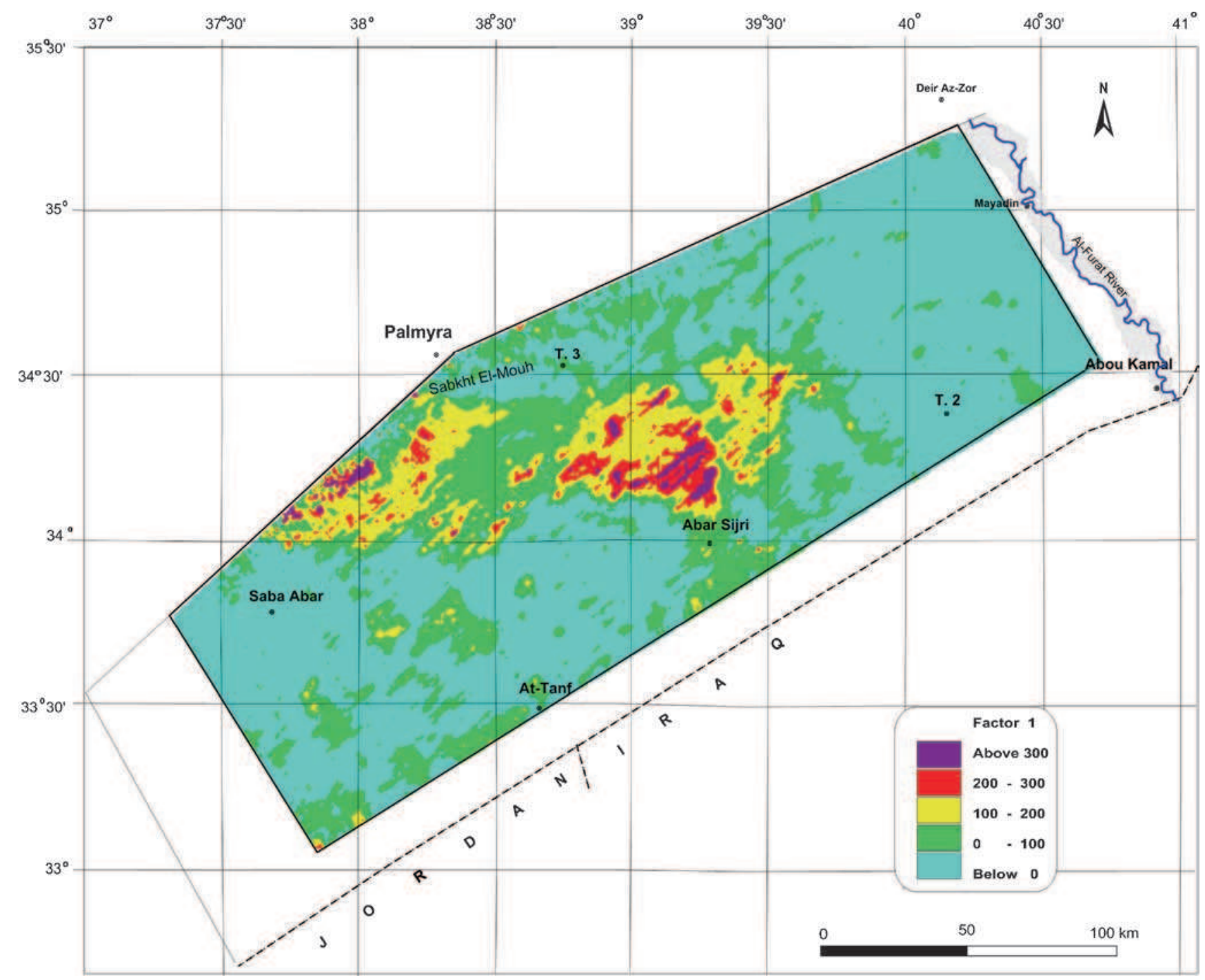

Figure 3. Score map of F1 in Syrian desert (Area-1).

anomaly (Carlisle 1980, 1983). The range of this unit does not exceed 100 on the F1 scored map.

Three lithofactor units have been distinguished according to the F2 scored map (figure 4). Those units are classified from the top to downwards as follows:

E: denotes the distribution of limestone, chalk-like marly limestone with phosphate intercalations, and silicious concretions and bands. This unit is not deeply affected by weathering, abrading, and leaching processes, where a limited amount of secondary uranium mineralization has been hosted by the act of ascending flow solutions through faults and extension fractures. Thus, the radioelement minerals are leached out from the adjacent phosphate rocks and concentrated in the voids and cleavages of the host rocks. The range of this unit exceeds 50 on the F2 scored map.
It is to be mentioned that some interferences between the above mentioned different lithofactor units $\mathrm{C}-\mathrm{D}$ and somewhat with E, could exist in the adjoining districts of volcanic zones, due to the leaching processes and accumulation within the evaporative ponds (takyrs). Those processes are mainly accompanied with subjacent movements of ascending hydrothermal solutions, where the secondary uranium mineralizations are concentrated inside silica facies (flint nodules) of interstitial textures and veinlets (Jubeli and Aissa 1998).

F: denotes the faults and extension fractures, accompanied with the ascending fluids. The range of this unit varies between -10 and 50 on the F2 scored map.

G: denotes the gradation of lithofacies from shallow, marine towards continental deposits, where the palaeo-shoreline is drawn (Asfahani et al. 2010b). The range of this unit does not exceed -10 . 


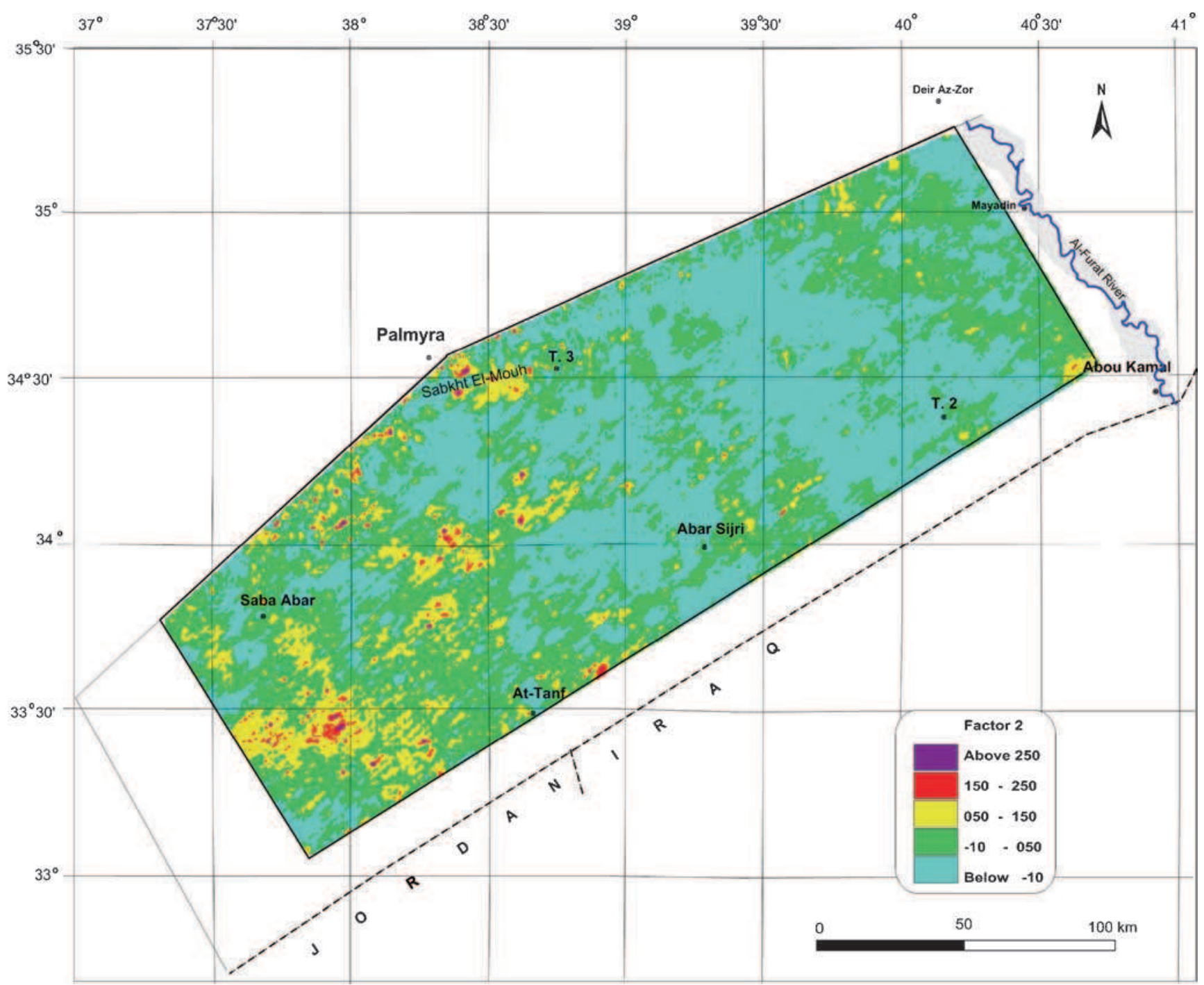

Figure 4. Score map of F2 in Syrian desert (Area-1).

Three lithofactor units have been distinguished according to the F3 scored map (figure 5). Those units are classified from the top downwards as follows:

$\mathrm{H}$ : defines the locations of closed basins, alluviums, and evaporative pans, where the weathering and leaching products of the adjoining surrounding rocks are accumulated in the lithofacies as a secondary uranium mineralization. This uranium accumulation is due to the upward movements of solutions from the subjacent soil horizons by the capillary action, or by the lateral leaching and abrading processes of adjoining outcrops. Those recent mineralization occurrences are difficult to be detected by the conventional spectrometric survey techniques (Carlisle 1980; Otton et al. 1989; Dickson and Wheller 1992). The range of this unit exceeds 30 on the F3 scored map.
I: denotes the distribution of the marginal parts of the evaporative pans, the locations of paleo-delta, which may form appropriate traps for secondary uranium minerals accumulation. The range of this unit varies between -10 and 30 on the F3 scored map.

J: defines the widespread grading continental litho-facies, composed of prevailing illuvations, sandy loams, detritus, and the illuvation of weathering and abrading products. The range of this unit does not exceed more than -10 on the F3 scored map.

The standard factor scored maps for F1, F2 and F3 have been thereafter used to establish the scored lithological map comporting the 10 different identified lithofactor units for Area-1 as shown in figure 6 .

The established lithological scored map with its identified units is useful for the prospecting of uranium mineralizations. This scored map will be the 


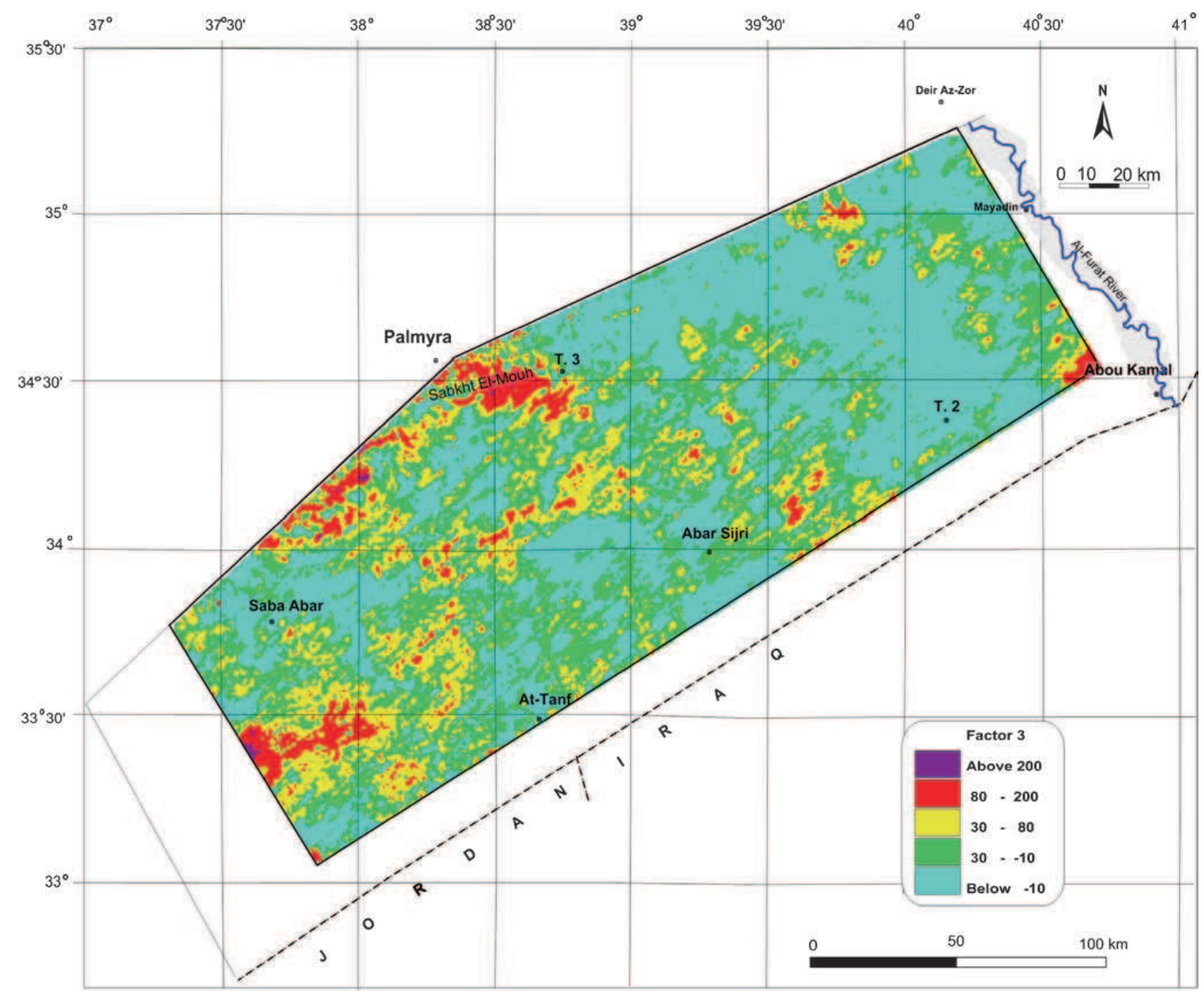

Figure 5. Score map of F3 in Syrian desert (Area-1).

base for future detailed research in Area-1, aimed at determining the mutual radioactive relationship between the different defined lithological units and evaluating the status of uranium mobility and its migration at regional scale (Asfahani et al. 2015).

Table 6 shows the ranges of the standard factor scores (F1, F2 and F3) characterizing the outlined rock units of Area-1, and the lithofactor description of those units.

A correlation has been done between the established lithological scored map shown in figure 6, the lithofacies succession and the sub-surface structures, with the help of available lithosections and data $\log$ distributed in the study area. A representative pseudo-section is selected as shown in figure 7 to be analyzed and used as a guide for uranium prospecting in Syrian desert (Area-1). The pseudo-section of about $285 \mathrm{~km}$ long passes by different distinguished lithofactor units, where different favourable traps for uranium prospecting are localized as follows:

1. The areas characterized by distinctive hallows of (F1: A, B, C and D) factor units and accompanied with a specific lithofacies are favourable for releasing and holding secondary uranium mineralizations by the contribution of surface and sub-surface leaching, as phosphates and other adjoined zones. Moreover, the presence of deep regional faults and extension fractures provoke the uranium accumulation processes by an ascending flow. Those hallows reflect districts of stratigraphic and structural potential traps of the secondary uranium mineralization (Sawwanet El-Hamra, w. El-Murabba'a, w. ElOwered, Abar Sijri....).

2. The areas characterized by hallows of (F2: E, $F$ and $G$ ) lithofactor units, which define the 


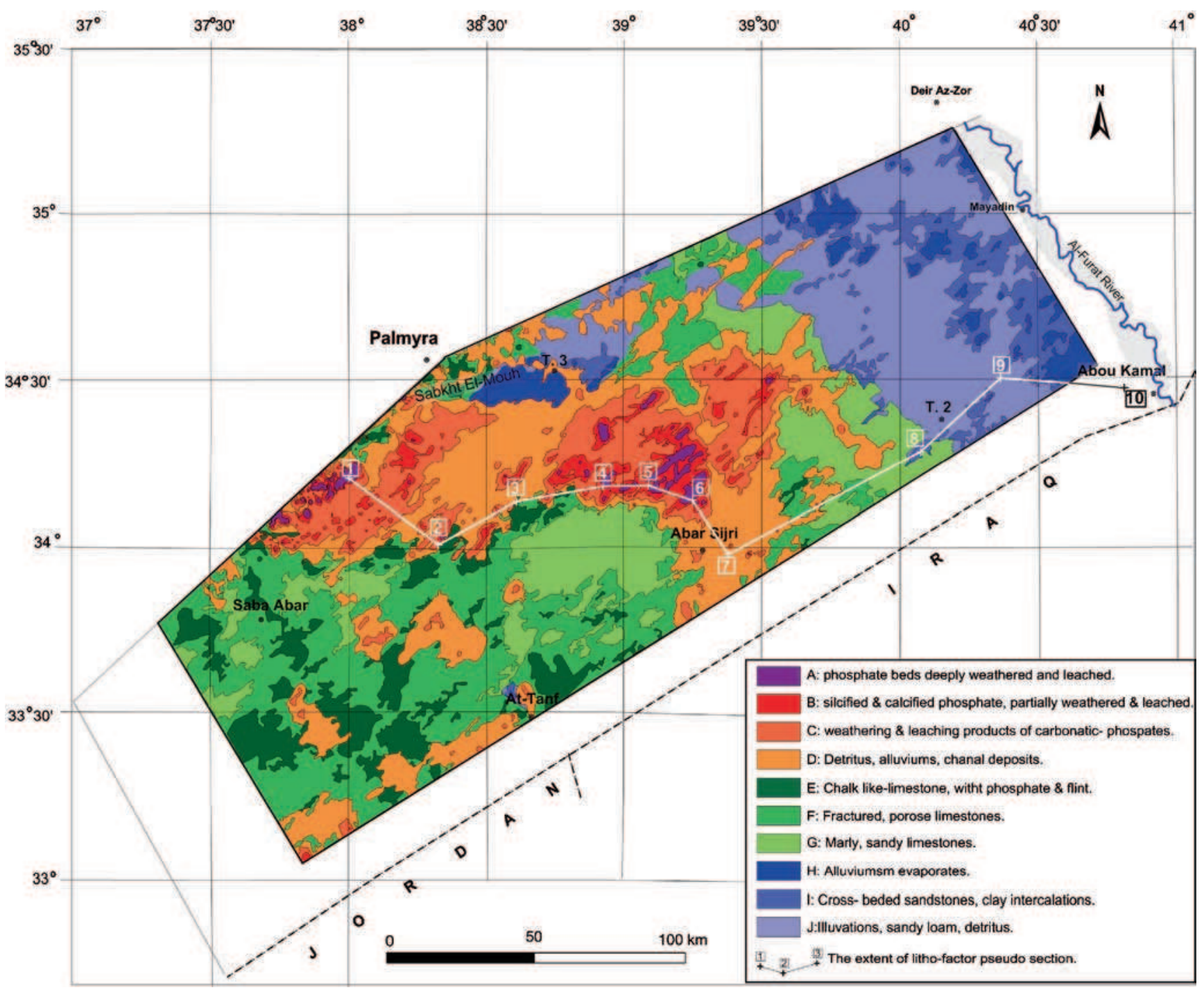

Figure 6. Radiometric lithological score map of Syrian desert (Area-1).

Table 6. Standard factor scores of the 10 units in Syrian desert (Area-1).

\begin{tabular}{|c|c|c|c|}
\hline Factor & Rock units & Lithofactor range & Description \\
\hline \multirow{4}{*}{ F1 } & A & $>300$ & Phosphate beds deeply weathered and leached. \\
\hline & $\mathrm{B}$ & $200-300$ & Silcified and calcified phosphate, partially weathered and leached. \\
\hline & $\mathrm{C}$ & $100-200$ & Weathering and leaching products of carbonatic- phosphates. \\
\hline & $\mathrm{D}$ & $<100$ & Detritus, alluviums, channel deposits. \\
\hline \multirow{3}{*}{$\mathrm{F} 2$} & $\mathrm{E}$ & $>50$ & Chalk like- limestone with phosphate and flint. \\
\hline & $\mathrm{F}$ & -10 to 50 & Fractured, porous limestone. \\
\hline & G & $<-10$ & Marly, sandy limestone. \\
\hline \multirow{3}{*}{ F3 } & $\mathrm{H}$ & $>30$ & Alluvium, evaporates. \\
\hline & $\mathrm{I}$ & -10 to 30 & Cross- bedded sandstones, clay intercalations. \\
\hline & $\mathrm{J}$ & $<-10$ & Illuvations, sandy loam, detritus. \\
\hline
\end{tabular}

regional and vicinal surface leaching, and somewhat a sub-surface leaching indicate distinctive lithofacies. Those facies serve as favourable stratigraphic traps for accumulating secondary uranim mineralizations as palaeo-shoreline, delta (w. AsSuwwab, w. El-Waar, W. El-Miyah).

3. The areas characterized by hallows of (F3: H, $\mathrm{I}$ and $\mathrm{J}$ ) lithofactor units, and distributed in 


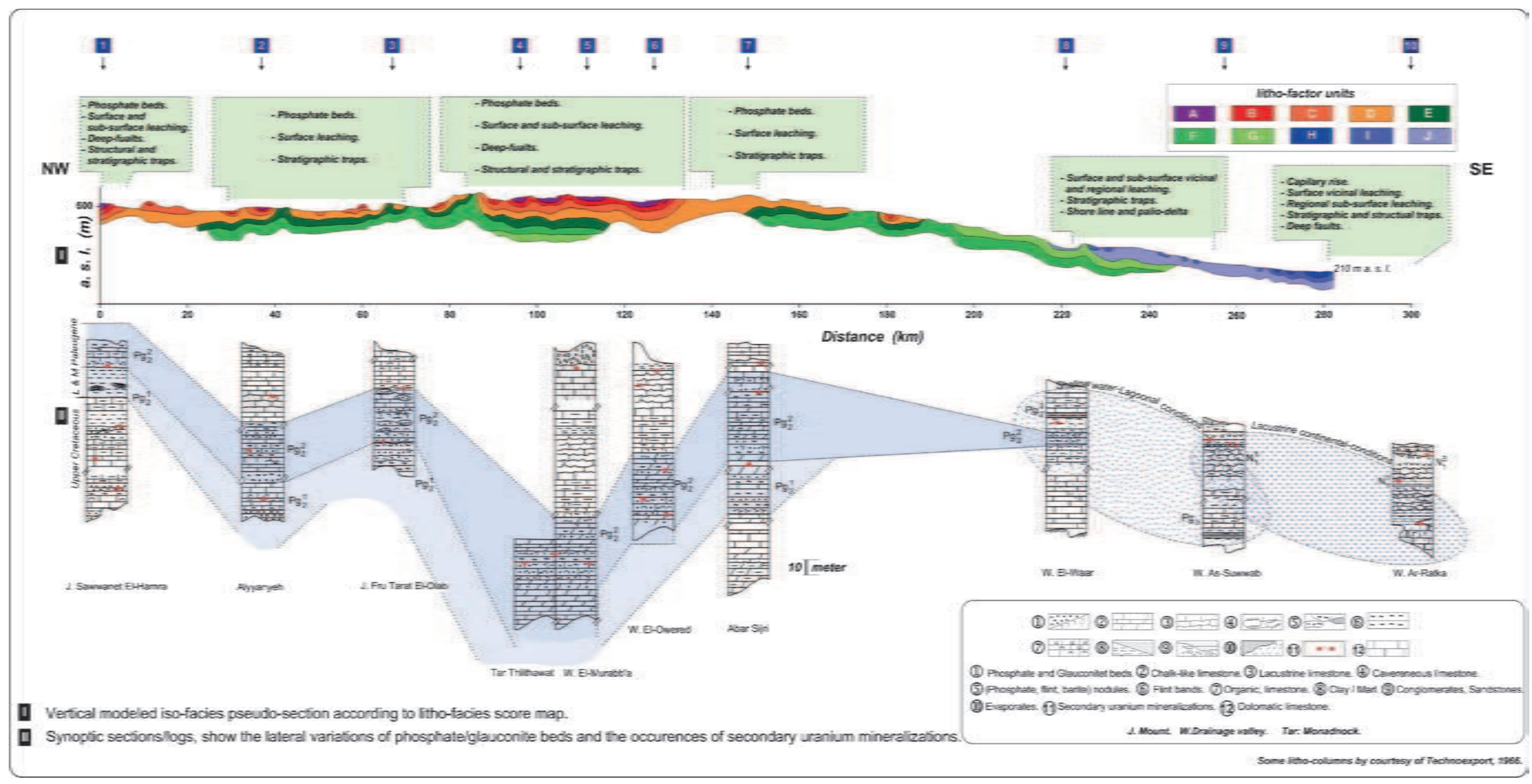

Figure 7. A representative pseudo-section profile passing by different distinguished lithofactor units. 
evaporative swales, sag ponds and channels, are not qualified as mature deposits, but could be considered as potential stratigraphic traps for secondary uranium mineralizations (w. As-Suwwab, Feidat Aj-Jub).

It is to mention that w. Ar-Ratka area has specific importance for uranium occurrences. This area with its regional characteristics must be studied in detail for uranium prospecting.

Finally, the vast study area with variety of lithofactor units showing radioactivity needs to be ground validated and if possible probed through sub-surface.

\section{Conclusion}

Lithological scored map containing 10 lithofactor units has been established through interpreting aerial spectrometric data of Area-1 by applying the statistical factor analysis technique. This technique shows high efficiency even when a huge number of data measured points are interpreted. The characteristics of the 10 lithofactor units have been defined through interpreting the established factor maps of F1, F2, and F3. Those defined lithofactor units will be the base for determining the status of the uranium migration and its mobility in the Area-1. A geological scored pseudo-section derived from the lithological scored map is established, where possible stratigraphic and structural traps for uranium occurrences are shown, explained and analyzed. Those localized favourable traps are the most promised districts in Syrian desert (Area-1) from a prospecting point of view, and necessitate more detailed future uranium exploration activities, including ground validation in a detailed scale and sub-surface well logging to evaluate their characteristics as a function of depth.

\section{Acknowledgements}

Dr I Othman, General Director of Syrian Atomic Energy Commission is thanked for his permission to publish this paper. Our deep and cordial thanks to the anonymous reviewers for their professional suggestions and remarks and for the intense English editing. Their contributions improved the final version of this paper remarkably.

\section{References}

Al-Bassam K S, Mahdi M A and Al-Delaimi M R 2006 Contribution to the origin of the syngenetic uranium enrichment in the early Miocene carbonates of the Euphrates formation, Iraq; Iraqi Bull. Geol. Mining 2 1-21.
Asfahani J 2002 Phosphate prospecting using natural gamma ray well logging in the Khneifiss Mine, Syria; Explor. Mining Geol. 11 61-68.

Asfahani J, Aissa M and Al-Hent R 2005 Statistical factor analysis of aerial spectrometric data, Al-Awabed area, Syria: A useful guide for phosphate and uranium exploration; Appl. Rad. Isot. 62 649-661.

Asfahani J, Aissa M and Al-Hent R 2007 Uranium migration in sedimentological phosphatic environment in northern Palmyrides, Al-Awabed area, Syria; Appl. Rad. Isot. 65 1078-1086.

Asfahani J, Al-Hent R and Aissa M 2009 Uranium statistical and geological evaluation of airborne spectrometric data in the Al-Awabed region and its surroundings (Area-3), northern Palmyrides, Syria; Appl. Rad. Isot. 67 654-663.

Asfahani J, Aissa M and Al-Hent R 2010a Aerial spectrometric survey for localization of favorable structures for uranium occurrences in Al-Awabed area and its surrounding (Area-3), northern Palmyrides, Syria; Appl. Rad. Isot. 68 219-228.

Asfahani J, Al-Hent R and Aissa M 2010b Geological and hydrogeological conditions for forming uranium occurrences in the Froqlos-Jabal Abou Rabah region, Palmyrides, Syria; Explor. Mining Geol. 19 1-12.

Asfahani J, Al-Hent R and Aissa M 2015 Uranium remobilization and migration evaluation through aerial spectrometric gamma technique in Syrian desert (Area-1); Appl. Rad. Isot., doi: 10.1016/j.apradiso.2015.11.004.

Bender F 1974 The geology of Jordan; Borntraeger, Berlin.

Comery A L 1973 A first course in factor analysis; Academic Press, New York, 316p.

Carlisle D 1980 Possible variations on the calcrete gypcrete uranium model; Open File Report, United States Department of Energy, GJBX-53-80, 38p.

Carlisle D 1983 World distribution relative to climate and physical setting; United Nation - International Atomic Energy Agency; Handbook on surficial uranium deposits.

Caron C and Mouty M 2007 Key elements to clarify the 110 M. Y. hiatus in the Mesozoic of eastern Syria; Geoarabia 12(2) $15-36$.

Dahlkamp F I 2009 Uranium deposits of the world, Asia; Springer-Verlag, Berlin.

Dickson B L and Wheller G E 1992 Uranium-series disequilibrium in exploration geology; In: Uranium-series disequilibrium: Applications to earth, marine, and environmental sciences (eds) Ivanovich M and Harmon R S, Oxford Science Publications.

Erd'ly M and Galfi J 1986 Surface and subsurface mapping in hydrology; Published in Co-edition with academia; Kiado Budapest, pp. 208-349.

Gavshin V M, Bobrov V A and Zorkina L S 1974 Quantitative relation between uranium and phosphorus in phosphorites and phosphatic sedimentary rocks; Litho. Min. Deposit. 6 118-126 (English transl. 740-746).

Hunting Geology and Geophysics Ltd 1975 Exploration and development in Syria; Report on Consultancy.

International Atomic Energy Agency 1988 Geochemical exploration for uranium: Technical Report Series 284, IAEA Vienna, 97p.

International Atomic Energy Agency 2014 IAEA Classification of uranium deposits; Patrice BRUNTON, IAEA Vienna-URAM 2014.

Jubeli Y M 1990 Uranium exploration in Syria SY/86/005, Final report; Atomic Energy Commission of Syria, Damascus.

Jubeli Y M 1997 The role of airborne radiometric survey in defining the distribution of phosphate rocks in Syria desert and the northern Palmyrides; Explor. Mining Geol. 6 269-278. 
Jubeli Y M and Aissa M 1998 Usage of geochemistry of uranium and associated elements to explain the anomalous non-phosphatic radiometric halo south west margins of Saba Abar Kherbet As-Sawwaneh area; Syrian Atomic Energy Commission Internal report, FRSR 183 Damascus (63p.)

Otton J K, Zielinsk R A and Been J M 1989 Uranium Holocene valley-fill sediments and uranium, radon and helium in waters, lake Tahoe-Carson range area, Nevada, California, USA; Environ. Geol. Water Sci. 13(1) 15-28.

Riso 1987 Aerial gamma-ray in Syria YR/87/005. Technical report; Riso National Laboratory, Roskilde, Denmark.
Rukieh M, Trifonov V G, Dodonov A E, Minini H, Ammar O, Ivanova $\mathrm{T}$ P, Zaza T, Yusef A, Al-Shara $M$ and Jobaili Y 2005 Neotectonic map of Syria and some aspects of Late Cenozoic evolution of the northwestern boundary zone of the Arabian plate; J. Geodyn. 40 $235-256$.

Sissakian V K 2007 The origin of the subsurface igneous clastics accumulation in Al-Tinif vicinity, west Iraq, a new concept; Iraqi Bull. Geol. Mining 3 11-24.

Technoexport 1966 Explanatory notes on the geological map of Syria, mineral deposits and underground-water resources; Ministry of Geology, USSR, 1967. 